\title{
RESULT OF AN EXPERIMENTAL SEEDING IN 1920 OF WHITE SPRUCE AND JACK PINE IN WESTERN MANITOBA
}

\author{
By R. A. HAIG
}

Robert A. Haig obtained a B.Sc.F. degree from the University of Toronto in 1949. He was employed by the Ontario Department of Lands and Forests on forest inventory and forest management work until 1953. Since that time he has held the position of liaison officer with the Forestry Operations Division of the Forestry Branch, Department of Northern Affairs and National Resources, at Winnipeg, Manitoba.

\section{ABSTRACT}

In 1920 varying amounts of white spruce and jack pine seed were sown on a series of small plots located on a well prepared seedbed of mineral soil. In 1957 only a few scattered specimens of jack pine survived, but the spruce plots supported a dense and apparently thrifty stand.

\section{INTRODUCTION}

The possibility of reforesting large areas quickly and economically by broadcast seeding has always had considerable appeal to foresters. Many seeding experiments have been undertaken to determine the feasibility of the method and to develop the necessary techniques. Although most such experiments have met with failure, this report describes one partially successful seeding carried out in the Duck Mountain Forest Reserve in 1920.

The purpose of this study was to determine the optimum amounts of jack pine (Pinus banksiana Lamb.) and white spruce (Picea glauca (Moench) Voss) seed to sow on a mineral soil seedbed in order to establish well-stocked stands of these species. A secondary purpose was to compare the development of jack pine and white spruce on the same site.

\section{Description of Experimental Area}

The area selected is immediately adjacent to the Grandview Ranger Station in the Duck Mountain Forest Reserve. The site is almost level and before treatment it supported a scattered stand of small aspen (Populus tremuloides Michx.), willow (Salix sp.), and birch (Betula papyrifera Marsh.). The soil is a sandy clay loam with a moisture regime varying from 1 to 2 and a pore pattern of about 4 according to the classification developed by Hills (5). In 1957, the soil profile was described as follows: $A_{0}$-about $1 / 4$ " of needle litter, $A_{1}$ about $1^{\prime \prime}$ of black loam, B-about $6^{\prime \prime}$ of dark brown structureless loam, and C-a yellowish brown sandy clay loam with some stones present.

\section{METHODS}

In May, 1920, six adjacent rectangular $1 / 4$-acre plots were established. The brush and trees were removed and burned and the plots were disked six times to break up the sod and provide a well-worked seedbed of mineral soil. Jack pine seed was broadcast by hand at rates of 2,3 and $4 \mathrm{lb}$. per acre on three of

Received for publication August 8, 1958. 
the plots, and white spruce was sown at rates of 1,2 and $3 \mathrm{lb}$. per acre on the other three plots. The area was then harrowed twice in order to cover the seed.

The plots have been remeasured seven times since establishment, each remeasurement being carried out in a somewhat different manner, although at each remeasurement date an attempt was made to determine the average number of trees per acre by tallying the trees on a portion of each plot.

In 1957, the tally was made on 100 per cent of the area of the jack pine plots, but because stocking appeared to be uniform and dense only 10 per cent of the area of the spruce plots was sampled.

\section{Establishment and Survival}

\section{RESUlts}

Table I shows the approximate number of trees per acre on each plot at each remeasurement date. Some inconsistencies will be noted in this table, for example the apparent increase in stocking of plots 4 and 6 between 1946 and 1957. No doubt these errors are due to inadequate sampling, and in some cases the remeasurements were made while snow was on the ground.

TABLE I

Survival of Jack Pine and White Spruce, Sown 1920 Duck Mountain Forest Reserve

\begin{tabular}{|c|c|c|c|c|c|c|c|c|c|}
\hline \multirow[b]{2}{*}{ Plot } & \multirow[b]{2}{*}{ Species } & \multirow{2}{*}{$\begin{array}{c}\text { Seed } \\
\text { Sown } \\
\text { (lb./acre) }\end{array}$} & \multicolumn{7}{|c|}{ Seedlings per acre } \\
\hline & & & 1921 & 1923 & 1924 & 1925 & 1929 & 1946 & 1957 \\
\hline 1 & $\mathrm{jP}$ & 2 & 43,560 & 4,840 & 970 & 6,290 & 3,190 & 30 & $\overline{20}$ \\
\hline 2 & jP & ( & 12,000 & 4,840 & 970 & 2,050 & 4,070 & 0 & 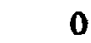 \\
\hline 3 & $\mathrm{jP}$ & 4 & 20,000 & 4,840 & 14,520 & 11,130 & 5,390 & 0 & 0 \\
\hline 4 & wS & 1 & 0 & 21,000 & 14,000 & 11,130 & 7,000 & 4,600 & 5,000 \\
\hline 5 & wS & 2 & few & 21,000 & 14,000 & 4,000 & 5,390 & 4,150 & 3,420 \\
\hline 6 & wS & 3 & 0 & 21,000 & 14,000 & 4,480 & 4,290 & 4,620 & 4,760 \\
\hline
\end{tabular}

It is evident that although initial stocking was very heavy, by 1957 regeneration of the plots sown to jack pine was a failure. In 1957, two of these plots had no survivors while the third had only about 20 trees per acre.

In contrast to the jack pine, the white spruce seeding was very successful. As indicated in Table $I$, the stocking in 1957 ranged from about 3,400 to 5,000 trees per acre which is actually too dense for trees of this age. There was no apparent correlation of stocking with the amount of seed sown, as the plot on which the least seed was sown had the heaviest stocking. There was little difference in the appearance of the stand on these three plots, and it is possible that the actual differences in stocking may have been less than indicated in the table.

It is difficult to assess what effects the various factors of the environment had on the early germination and survival of the seedlings. However, in this as in any seeding experiment, precipitation undoubtedly was a major factor. Weather records for Dauphin, the meteorological station nearest the plots, in- 
dicate that in 1920 the precipitation during the May to September period was nearly two inches below normal (3). No seedlings were noted when the plots were examined in October of that year. In the following year, May to September precipitation was nearly two inches above normal. That fall the jack pine plots were heavily stocked, but scattered seedlings were observed on only one of the white spruce plots. It is possible that, being considerably smaller than jack pine, the first-year spruce germinants may have been overlooked. It seems unlikely that conditions evidently so favorable for jack pine would fail to cause germination of white spruce. Below normal precipitation was recorded in 1922 and 1923 and the remeasurements made in the fall of 1923 indicated a sharp decline in jack pine numbers although the white spruce plots were uniformly and heavily stocked. Once the seedlings were well established, minor fluctuations in the rainfall pattern probably ceased to be the critical factor governing survival.

After examining the plots in 1929 , C. B. Gill stated that the tips of the taller seedlings of both pine and spruce were eaten off by rabbits (Lepus americanus) in 1924, a year in which the rabbit population reached its cyclic peak (4). He said also that willow suckers appeared to be retarding the growth of the pine but not the spruce. The next peak in the local rabbit population is known to have occurred in $1933 .^{1}$ Table I indicates that jack pine was virtually eliminated between 1929 and 1946, while losses of white spruce were relatively light. Studies made in the Lake States, (1), (2), (7), indicated that rabbits prefer jack pine to white spruce, and that the former is less able to recover from the usual type of rabbit damage. These may be the reasons why in this instance jack pine almost disappeared while spruce showed only a moderate decline in numbers.

Aspen was present on all plots in 1957. The trees ranged from one to seven inches d.b.h. and their average height was greater than either the pine or spruce. Two of the spruce plots had less than 100 aspen stems per acre while the third had more than 400. On the jack pine plots aspen ranged from 200 to 1,100 stems per acre, and this may have had an adverse effect on the survival of the intolerant pine. Any reduction in height growth caused by suppression would increase the period during which the seedlings were vulnerable to rabbit damage. Aspen did not appear to have had a marked effect on the spruce.

It is interesting to note that white spruce volunteer growth was recorded on all the jack pine plots in 1946 and 1957. In 1957, these trees ranged from 1 to 7 inches d.b.h., the average being about 3 inches. Their numbers ranged from less than 50 to 190 trees per acre. There are a few mature spruce adjacent to the plots and no doubt the volunteers originated from seed shed by these trees. The volunteers appeared to be about the same age as the stand on the spruce plots, and it is likely that they germinated when seedbed conditions were still favorable as a result of treatment.

\footnotetext{
${ }^{1}$ Correspondence from C. B. Gill, Chief of Forest Management, Manitoba Forest Service, Winnipeg, Manitoba.
} 


\section{Height and Diameter Growth}

Table II shows, for each plot, the average heights of the trees in 1929, 1946 and 1957 and their average diameters in 1946 and 1957.

TABLE II

Growth of Jack Pine and White Spruce, Sown 1920 Duck Mountain Forest Reserve

\begin{tabular}{cccccccc}
\hline & & \multicolumn{7}{c}{ Year of Measurement } \\
\cline { 3 - 8 } Plot & Species & $\begin{array}{c}\text { Av. d.b.h. } \\
\text { (inches) }\end{array}$ & $\begin{array}{c}\text { Av. ht. } \\
\text { (feet) }\end{array}$ & $\begin{array}{c}\text { Av. d.b.h. } \\
\text { (inches) }\end{array}$ & $\begin{array}{c}\text { Av. ht. } \\
\text { (feet) }\end{array}$ & $\begin{array}{c}\text { Av. d.b.h. 1957 } \\
\text { (inches) }\end{array}$ & $\begin{array}{c}\text { Av. ht. } \\
\text { (feet) }\end{array}$ \\
\hline 1 & jP & - & 0.6 & 1.6 & 11.8 & 3.1 & 21.0 \\
2 & jP & - & $?$ & - & - & - & - \\
3 & jP & - & 1.1 & - & - & - & - \\
4 & wS & - & 0.7 & 1.0 & 9.2 & 2.3 & 18.8 \\
5 & wS & - & 0.8 & 1.2 & 9.7 & 2.5 & 21.6 \\
6 & wS & - & 1.0 & 1.0 & 9.2 & 2.4 & 23.4 \\
\hline
\end{tabular}

It is indicated that although height growth was fair during the last 11-year period, it was slow prior to that time. In 1946, 26 years after sowing, the average height of the spruce was less than 10 feet, while that of the few surviving pine was less than 12 feet. The average heights of both species nearly doubled between 1946 and 1957.

It is likely that rabbit damage occurring in 1924 (and possibly again around 1933 ) is partly responsible for the slow early growth rates. Another reason for slow growth may be the drought conditions that prevailed for nearly a decade on the prairies. Normal precipitation at Dauphin during the May to September period is 10.6 inches, but from 1928 to 1936 it was below normal in all but two years. The average annual precipitation was 3.4 inches below normal (3). Pearson (6) showed that on dry sites there was a close relationship between annual height increment and precipitation during the growing season. In this case, the study site is somewhat dry (1 to 2 moisture regime) and it is reasonable to suppose that a long period of below-normal precipitation would retard height growth.

The overly dense stocking of the spruce plots undoubtedly increased the adverse effects of the inadequate moisture supply, but although these two factors evidently had marked effects on growth, they did not cause heavy mortality. Jack pine survival declined sharply between 1929 and 1946, but as indicated earlier, rabbit damage, and to a lesser extent suppression by aspen and willow, are believed to be the causes of this decline.

During the 11-year period between the last two remeasurements, the mean annual diameter and height increments on the spruce plots were about 0.12 inch and 1.1 feet respectively. Considering the extreme density of the stand on these plots, this growth rate is considered to be fairly rapid. 


\section{Health}

There was no sign of insect or disease attack on the spruce plots, and except for the effects of suppression due to overstocking, the trees appeared to be healthy. Tree form was good, and although there was little evidence of natural pruning, the branches were dead on the lower 5 to 7 feet of most stems. Because of overstocking, it is likely that in the next ten years there will be a decline in the growth rate and an increase in mortality.

In contrast to the white spruce the few jack pine surviving in 1957 did not appear to be healthy. Their foliage was thin and pale, and their trunks bore basal scars which were probably the result of previous rabbit damage.

\section{SUMMARY}

In May 1920, three $1 / 4$-acre plots located in the Duck Mountain Forest Reserve were thoroughly disked and sown with varying amounts of jack pine seed, and three adjacent plots were similarly treated and sown with white spruce seed. The plots were remeasured in 1921, 1923, 1924, 1925, 1929, 1946 and 1957 , to trace the establishment, survival and growth of the seedlings.

Initial establishment of both species was dense and did not appear to be correlated with the amount of seed sown. Heavy growing-season rains during the year following sowing evidently induced a high percentage of germination.

Jack pine was virtually eliminated between 1929 and 1946 but the white spruce plots were still heavily stocked in 1957 (3,400 to 5,000 trees per acre). Rabbit damage is believed to be the chief cause of the decline in jack pine numbers.

For the frrst 26 years after the plots were sown, both species grew rather slowly, but in the last 11-year period spruce growth appeared to be normal. Rabbit damage, suppression, drought and overstocking are the factors largely responsible for the slow early growth rates.

In 1957 , the white spruce appeared to be healthy, but in the near future, overstocking is expected to cause some mortality and a reduction in the growth rate. The few jack pine surviving in 1957 did not appear to be thrifty.

These results suggest that, under favorable conditions, dense stands of white spruce and jack pine can be established by broadcast seeding, and that, once established, the former species can maintain adequate stocking in spite of drought and rabbit damage.

\section{ACKNOWLEDGMENT}

Mr. H. J. Johnson, Forester, Forestry Branch, Department of Northern Affairs and National Resources, Calgary, Alberta, provided assistance in the securing of the field data on which this report is based. This assistance is gratefully acknowledged by the writer.

\section{REFERENCES}

1. ANON. 1936. Woody food preferences of the snowshoe rabbit in the Lake States. U.S.D.A. For. Serv., Lake States For. Exp. Sta., Tech. Note No. 109.

2. ANON. 1936. Rabbits cause great losses to plantations in bushy areas. U.S.D.A. For. Serv., Lake States For. Exp. Sta., Tech. Note. No. 116.

3. ANON. Monthly Weather Records. Canada, Dept. of Transport, Meteorological Division.

4. GILL, C. B. 1929. Unpublished M.S. 
5. HILLS, ANGUS. 1952. The classification and eraluation of site for forestry. Ontario, Dept. of Lands and Forests, Division of Research, Research Report No. 23.

6. PEARSON, G. A. 1918. The relation berween spring precipitation and height growth of western yellow-pine saplings in Arizona. J. For. 16:677-689.

7. STOECKELER, J. H. and L. W. KREFTING. 1954. Effect of simulated snowshoe hare and deer damage on some conifers planted in the Lake States. U.S.D.A. For. Serv,, Lake States For. Exp. Sta., Tech. Note No. 413. 